\title{
Development of the Concept of Circular Supply Chain Management-A Systematic Review
}

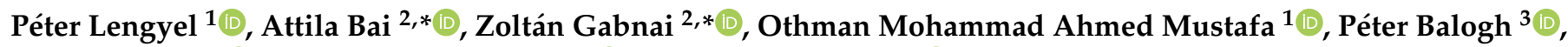 \\ Erzsébet Péter ${ }^{4}{ }^{(}$, Nikoletta Tóth-Kaszás ${ }^{4}$ and Kornél Németh ${ }^{4}$ (D) \\ 1 Institute of Applied Informatics and Logistics, Faculty of Economics and Business, University of Debrecen, \\ H-4032 Debrecen, Hungary; lengyel.peter@econ.unideb.hu (P.L.); \\ othman.mustafa@econ.unideb.hu (O.M.A.M.) \\ 2 Institute of Applied Economics, University of Debrecen, H-4032 Debrecen, Hungary \\ 3 Department of Statistics and Methodology, University of Debrecen, H-4032 Debrecen, Hungary; \\ balogh.peter@econ.unideb.hu \\ 4 Institute of Applied Management Sciences, University of Pannonia Nagykanizsa-University Center for \\ Circular Economy, H-8800 Nagykanizsa, Hungary; peter.erzsebet@uni-pen.hu (E.P.); \\ kaszas.nikoletta@uni-pen.hu (N.T.-K.); nemeth.kornel@uni-pen.hu (K.N.) \\ * Correspondence: bai.attila@econ.unideb.hu (A.B.); gabnai.zoltan@econ.unideb.hu (Z.G.)
}

Citation: Lengyel, P.; Bai, A.; Gabnai, Z.; Mustafa, O.M.A.; Balogh, P.; Péter, E.; Tóth-Kaszás, N.; Németh, K. Development of the Concept of Circular Supply Chain Management-A Systematic Review. Processes 2021, 9, 1740. https:// doi.org/10.3390/pr9101740

Academic Editor: Jui-Yuan Lee

Received: 18 August 2021

Accepted: 24 September 2021

Published: 28 September 2021

Publisher's Note: MDPI stays neutral with regard to jurisdictional claims in published maps and institutional affiliations.

Copyright: (c) 2021 by the authors. Licensee MDPI, Basel, Switzerland. This article is an open access article distributed under the terms and conditions of the Creative Commons Attribution (CC BY) license (https:// creativecommons.org/licenses/by/ $4.0 /)$.

\begin{abstract}
This systematic review presents the most important characteristics and trends of research in circular supply chain management (CSCM), taking into account the impact of COVID. In addition, the similarities and differences between the basic concepts often used as synonyms for sustainability are also presented. First, the sample database (39,000 records) was based on a search containing publications' titles regarding supply chain management (SCM). After narrowing the topic from SCM towards CSCM, the considered paper characteristics were expanded, including abstract and author keywords, to get a manageable number of samples for the systematic analysis (6095 documents) and the most accurate results possible. The analysis' base sample was divided into two periods (before and after 2012) due to a significant increase and change in the number of publications, their subject, characteristic journals and geographical location. Sustainability has emerged since 2012, while a circular approach emerged after 2017 with a significant share of research, mainly thanks to relevant EU policies. Although the role of the US has been decisive in the field, the European research bases of previous years have increasingly been replaced by Far Eastern dominance. Currently, CSCM's most important journal is the International Journal of Supply Chain Management (Elsevier), but most articles on the impact of COVID have been published in Sustainability (MDPI). More effective policy implementation and the fight against COVID in the development of supply chains are also likely to spread the circular economic model in the future.
\end{abstract}

Keywords: SCM; CSCM; COVID; policy; green; sustainable; circular; review

\section{Introduction}

The twentieth century was characterized by an increase in research into the interactions between the growth of the economic system and the issues of environmental degradation. Globalization has led to a huge increase in international trade and the emergence of global value chains. Antiglobalization voices and the emphasis on the need for a green transition are coming to the fore. It would be overly optimistic to assume that environmental sustainability will be a priority in the context of economic relaunch but putting demand and supply-side actors in many sectors on a 'green' path as soon as possible, as well as pursuing sustainable, resilient supply chains are inevitable.

The joint implementation of economic, social and environmental aspects must be realized by using the technological solutions and theoretical knowledge of the twentyfirst century. This requires companies that face the constraints of natural resources, the 
compulsion to manage them wisely and the conscious involvement of institutions and households alike. For sustainability efforts to succeed, the importance of changing attitudes must be emphasized more than ever. In addition to forcing the rethinking of consumer society, there is a need for processes that can maintain current productivity in whole or in part but all this with a rethought, reduced material and energy demand.

As a result of the changes of today and that have taken since the turn of the millennium, the development of supply chain management (SCM) has received a new impetus and direction, focusing on sustainability and resilience, which require a clear definition of related concepts and scientific research.

Regarding the structure of the paper, the literature part provides insight into the trends and material flows in the world economy, then it was narrowed down to the challenges of SCM, focusing on the circular aspect. The similarities and differences between the basic concepts often used as synonyms for sustainability, the temporal changes and current trends in the emergence of the five most important categories have been emphasized. The next section contains the description of the considered basic sample and the methodology of the applied systematic review. In the end, the findings are presented, related to a keyword co-occurrence network analysis regarding SCM in two well-separable time periods, on the subareas of SCM (most relevant papers and journals, the spatial transformation of research sites) and a short analysis on the impact of COVID-19.

\section{Literature Review}

\subsection{The Role of Global and Local Trends in World Economic Processes}

The globalization of supply chains makes it difficult to manage and control them. At the same time, global resource use and pressure on the environment are constantly increasing [1-3]. During the coronavirus pandemic, a number of previous challenges have come to the fore, among others: the complexity of international supply chains; the cross-border dependency system as a risk factor; the opacity of supply chains; unexpected crises; developments in international trade policy trends; political factors; promoting environmental and social responsibility; the expectations of some multinational companies towards partners or even countries; cultural differences [4-8].

According to Koberg and Longoni (2019) [9], in the future it will be important to take into account the nontraditional actors appearing in the system, such as government institutions, producer associations, chambers of commerce, social actors or nonprofit financial organizations. Nevertheless, in global supply chains it is also important to examine the relationships with management and suppliers, the initiatives and the cooperation with NGOs at the local and international levels.

While problems with the use of natural resources and the climate issue is a slow, intergenerational process, the COVID-19 pandemic has shocked the world in a very short time, without warning. The pandemic affected all walks of life, fundamentally changing not only the everyday life but also the functioning of politics, institutions, governance and communication. In addition to sectors directly exposed to the coronavirus crisis (tourism), sectors indirectly exposed (such as the car industry) will face more serious challenges in both the short and long term. At the same time, the pharmaceutical industry, companies manufacturing medical devices, as well as the field of infocommunications have been able to grow.

The issues raised against the processes of globalization, the obviously unfavorable environmental, social and economic effects of the system have strengthened localization as opposed to globalization.

Localization can be used as a strategy to remedy the harmful socio-ecological effects of economic globalization and its re-creation can lead to improved sustainability outcomes. Positive localization is a sustainable, socially just process that helps communities, economies and the environment to meet basic needs through local governance, ownership, trade and resource use with the least possible political, economic and resource dependence $[10,11]$. However, as in the case of global world economic phenomena, it is 
not possible to speak about only the positive aspects of localization. The complexity of the issue is discussed by Benedek et al., (2020) [12] with regard to the food industry and by Németh et al., (2020) [13] concerning locally produced energy. European and global businesses are increasingly moving towards sustainable value chains. Supply chains in local and smaller districts are often encouraged through concrete policy initiatives [14,15]. The European Environment Agency's professional paper on the subject emphasizes the need to better understand the environmental and social impacts of today's changes in supply chains [16]. According to the authors' opinion, educational research institutions and various professional organizations should not only take part in this, but also play a leading role. The authors consider it extremely important-and one of the aims of this study - to compare the latest research results in this field. Their analytical assessment can help the government and businesses involved make associated decisions.

An epidemic has always been a milestone that has forced intellectuals to reevaluate the directions of development. Possible reactions to the new situation have in many cases provoked lively debates throughout history pointing to the vulnerability of the socio-economic structures at the given period and the need to rethink the current way of development [17]. It is not different today.

\subsection{Material Flows in the World Economy}

Looking at today's economic processes as a whole and analyzing trends in consumption patterns, a steady increase in resource use can be observed. Global sustainable resource use is the focus of several studies [2,18-20]. Global extraction and processing of natural resources account for more than $90 \%$ of biodiversity loss and water pollution and about half of the effects of climate change [21]. The constant and rapid growth of the variety of materials means that more and more complex products are being created and more and more materials are being used both quantitatively and qualitatively [22].

According to the European Commission's 'The European Green Deal' (2019), annual global raw material extraction tripled between 1970 and 2017 and has been growing ever since [23]. Kunzig's (2020) [24] paper titled 'Our world without waste?', with reference to Circle Economy Strategic Alliances' data from 2015, summarizes the world's material flows and the complex processes behind them as follows:

- 93 billion tons of raw materials (e.g., minerals, ores, fossil fuels and biomass) were extracted in nature;

- We convert 102.3 billion tons of raw materials into products annually. A quarter of these become buildings, cars or other durable things;

- Less than $10 \%$ (9.3 billion tons) of the material returns to the economy. They are reused through composting, recycling, soil improvement, biogas production and wastewater treatment;

- $\quad 67.4$ billion tons, i.e., two-thirds of the materials flowing through the economy, were emitted as waste or, for example, as carbon dioxide from fossil fuels at the end of the process;

- $\quad 23.7$ billion tons were 'durable materials', such as end-of-process buildings and other infrastructure.

Hence, humanity converts more than 100 billion tons of raw materials into products every year. These materials have become products to meet the following seven human needs: housing, communication, mobility, healthcare, services, consumer goods and food. The resource and carbon footprint of societies is mainly related to the basic needs of food supply, living, housing and transport/mobility [25,26], so there is a need to increase resource efficiency in these areas in particular.

According to the technical paper of the United Nations [27] on the topic, four types of raw materials play a role in the material flow processes of the world economy: minerals, ores, fossil fuels and materials of biological origin. This is projected to increase in the coming decades; resource extraction with current production methods and consumption patterns could double by 2050. The most significant growth is expected for minerals and 
materials of biological origin. In addition to growth, global resource use is also changing by region. While in 2000 high-income countries were net importers, all other regions were net exporters. High-income countries now export one billion tons of material, with exports from the United States and Australia growing rapidly. Exports from the upper-middleincome countries are approximately 750 million tons. In 2017, the material footprint in the Pacific was estimated at 11.4 tons per capita. In North America, the final material consumption per capita is 30 tons. It is 20.6 tons in Europe and less than 10 tons in all the other regions.

On the other hand, supply chains that focus on sustainability considerations and are specifically based on the circular economic model can bring about the more favorable development of these trends if they are widely used in global supply processes.

In the context of the above processes and in line with supply chain sustainability issues, the need for intervention is clear. Several regions, countries and manufacturing companies have turned to developing long-term strategies. Following global trends, several approaches have emerged in this regard: definitions based on the waste hierarchy [28-33]; resource-oriented definitions [34-36]; economy-focused definitions [37-39]; cross-industry networking, industrial symbiosis approaches [1,40-43]; material cycle definitions [44-47].

It is clear that the time has come to rethink global supply processes and consumption patterns more urgently than ever before. One tool for this could be the circular economic model. The umbrella concept of the circular economy combines previous approaches to form a kind of innovation framework, meaning a reinterpretation of economic, social and environmental processes and chains of impact with sustainability in mind. It summarizes the theories that have emerged in recent decades in the field of environmental economics and ecological economics [48-51].

Sustainability challenges call for urgent, comprehensive and coordinated action in global and local supply chains. In this respect, the European Commission's new action plan for a cleaner and more competitive Europe regarding circular economy in March 2020 is a step forward [52]. The new plan aims to extend the circular economy from precursors to major economic players and accelerate the transformation required by the European Green Deal. To this end, the areas identified by the Commission as key value chains are as follows: electronics, information and communication technologies (ICT); batteries and vehicles; packaging; plastics; textile industry; construction and buildings; food; water and nutrients. Focusing on these areas clearly moves supply chains towards sustainability and the circular economic model.

\subsection{The Development of Supply Chain Management: Today's Challenges}

Supply Chain Management (SCM) can be identified as a multidisciplinary field of research that has been evolving since the late 1990s, constantly seeking answers to current challenges and problems $[53,54]$. Supply chain management is an activity that integrates key processes from the manufacturer to the end-user, creating a product, service and information that is of value to consumers and other stakeholders [55]. The supply chain process ranges from the extraction of raw materials to the delivery of finished products to end users, and also includes various services related to the product (e.g., service, waste management, recycling). The supply chain is built on information systems and includes manufacturing, marketing and financing, strategic resource planning, business process relationships, risk sharing and the involvement of supply providers in product development [56]. In a well-functioning society supply chain management creates jobs, reduces pollution and energy consumption and raises living standards [57].

The Earth's population, economic performance and living standards are gradually increasing, which is closely linked to resource overexploitation and environmental degradation [58]. In this sense, making supply chains more sustainable is one of the great challenges facing humanity. From time to time, the events of recent decades or years have drawn attention to the vulnerability of global supply chains. 
The world has already experienced several catastrophic industrial accidents: the largest oil disaster caused by the oil tanker Amoco Cadiz on 16 March 1978 (in France); the largest chemical plant accident, better known as the Bhopal gas tragedy on 2 December 1984 (in India); the Chernobyl nuclear disaster on 26 April 1986 (in Ukraine); the Exxon Valdez oil disaster on 24 March 1989 (in the USA) (Rajeev, 2017). The trade route recently blocked by a huge container carrier running ashore in the Suez Canal, the damage to infrastructures caused by extreme weather, the sanctions resulting from the rivalry between China and the USA, the restrictions caused by the pandemic and the raw material shortage are all events that force stakeholders (including regulators, manufacturers, customers and the public) to review their economic and business models. The impact of many business practices on society and the environment comes to the fore again and again. New trends and concepts are emerging in connection with SCM, and the implementation and incorporation of sustainability aspects have begun in an increasingly targeted manner.

In recent decades, supply chains, including the related literature, as well as research directions, have undergone radical changes and several evolutionary phases $[59,60]$. In the 1970s, the theory of growth poles was dominant, and the supply chain was interpreted as a star-shaped system influenced by vertical, dyadic customer-supplier relationships. In the 1980s, the supply chain became a pyramid-shaped system influenced by the mutual trust between the customer and first-tier suppliers [61,62]. Mutually beneficial customer/buyer and supplier relationships have been positively influenced by information and knowledge sharing processes [63]. In the 1990s, the main topics in the supply chain literature were strategic collaborative and competitive alliances between companies and various customer-led initiatives [64]. Since the 2000s, environmental awareness has come to the fore in the area, thanks to the various climate change agreements and the expectations and requirements defined by them. All of this is crucial for individual companies as well as for supply chains $[60,65]$. The gradual prominence of environmental protection and climate protection, the compulsion to meet current objectives and standards has resulted in a transformation of research directions related to supply chains in the last decade. These have been identified through sustainability issues, environmental management strategies and the practical application of the new opportunities offered by the circular economy and green supply systems [66-74].

\subsection{Consideration and Definition of Sustainability Aspects in Supply Chain Management}

Changing current production and consumption patterns is essential both to avoid depletion of natural resources and to avoid environmental and climate-related disasters [75]. Although the relationship between sustainability as a concept and supply chain management has become increasingly important in recent times, global production, consumption and trade remain on a rather unsustainable path $[35,69]$. There are huge discrepancies between ecosystem services, the Earth's potential sustainability and today's modes of production and consumption. The issue is further complicated by climate change and its challenges to be solved. The examined topic is directly related to most of the sustainable development goals formulated by the United Nations [14].

In parallel with the phenomena presented in the previous chapters, with innovative efforts related to supply chain management, new concepts began to spread in the literature. Among the new concepts and models, we can mention the following ones [76-80]:

- Environmental supply chain management-ESCM;

- $\quad$ Sustainable supply chain management-SSCM;

- Green supply chain management-GSCM;

- Closed-loop supply chain management-CLSCM;

- Circular supply chain management-CSCM.

In addition to the above approaches, the concepts of low-carbon, eco-friendly, responsible or even flexible (resilient) supply chain are also present (Figure 1.). 


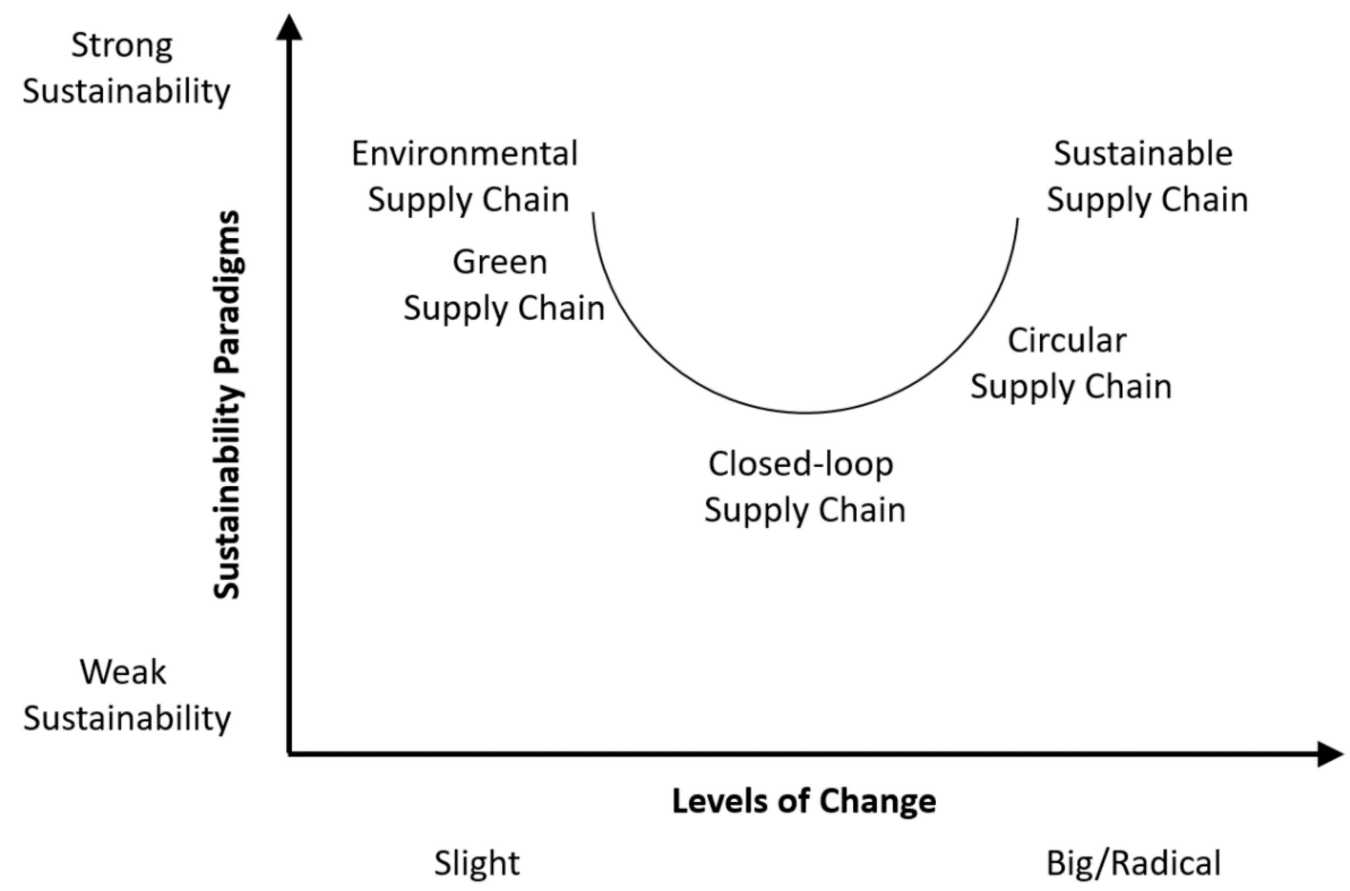

Figure 1. Main features of the SCM types examined (aspects: sustainability paradigms and levels of change).

The previous concepts represent different levels of sustainable, environmentally conscious thinking in relation to supply chains. None of them systematically integrates circular thinking into the SCM [81]. Each category is also used as a synonym by most researchers and economists [80]. These are indeed similar, but not identical concepts, that is why the authors consider it important in this research to present the differences between them. According to Ahi and Searcy (2015) [82], these concepts essentially mean different levels of consideration of sustainability aspects in SCM-related decisions.

Geissdoerfer et al., (2017) argue that sustainability encompasses environmental, social and economic aspects, while the circular economy (CE) primarily emphasizes the latter. It mostly refers to short-term individual economic benefits by reducing costs, increasing efficiency and avoiding waste generation. In contrast, sustainability is a category that can only be interpreted in the longer term. Another difference is the type of participants and initiators, according to which the role of social organizations is decisive in environmental protection, while in the circular economy the emphasis is clearly on governments and companies [83].

The term 'green' is typically used to describe a product or service that focuses on the wider environment and climate protection. The terms eco-friendly and environmentally friendly are very similar but with a narrower sense, meaning being less harmful or harmless to the environment than any other benchmark [84]. When examining the semantic areas of 'green economy' based on the analysis of a database of 877 relevant literature, Loiseau et al., (2016) [85] found the following keywords dominant: environmental dimension, resources; practical implementation, environmental policy; geographical areas, China; tools, LCA; sectors, industry. However, the article also emphasized that there are terms that do not appear among the keywords in the scientific literature but may be important in practical work to study the topic. These include: green infrastructure [86]; bioeconomy [87]; product-service system [88].

An important element in the transition from traditional or sustainable supply chain management to closed-loop (CLSCM) and circular supply chains (CSCM) is the implementation of a 'longer cycle', which includes extending the shelf-life of materials [89]. This can be achieved by extending the durability of products or increasing the number of consecutive cycles of remanufacturing, repair, refurbishment and recycling. The inner 
loop and longer 'circling' can be implemented more efficiently for parts of durable goods, while less so for fast-moving consumer goods [90]. All in all, the CE is not necessarily sustainable. Two typical examples of unsustainable circular business models are Uber and Airbnb, which also take social risks to increase profits. Among the products, the production of bioplastics and biofuels clearly meets the requirements of the $\mathrm{CE}$, and they are often labelled 'eco-friendly' but their social and environmental friendliness is questioned by many (especially environmental organizations), while economic decision-makers mostly prefer their production [91].

Analyses by Ahi and Searcy (2013) [92] and Srivastava (2007) [93] have shown that until the early 2010s, none of the definitions of 'green' SCM explicitly mentioned social issues from the environmental socio-economic elements of sustainable SCM. In addition, only economic and environmental elements appear in the definitions of 'environmental' SCM and 'closed-loop' SCM, omitting the social factor [94,95]. The SCM model of Khorshidvand et al., (2021) [96] for optimizing the pricing of refurbished products seeks to maximize profits and minimize $\mathrm{CO}_{2}$ emissions by also taking into account the green commitment of potential buyers in order to reduce demand uncertainty. According to the analyses of Faroouque et al., (2019) [81], the terms most often associated with the term ' $\mathrm{CE}^{\prime}$ in the keywords of scientific articles were 'production', 'consumption', 'design' and 'waste management' with a prevalence of over $10 \%$, 'CE' lagging behind them with around $5 \%$.

Although the need for sustainability has been reflected in the work of social organizations and in the literature for decades, production, consumption and trade still have unsustainable characteristics [35]. This was also true of SCM until recent years [69,97]. The Ellen MacArthur Foundation [98] also emphasized the loss-minimizing nature of the CE in industrial processes. However, integrating the CE into SCM can clearly provide sustainability benefits. According to Genovese et al., (2017) [99] and Nasir et al., (2017) [100], the circular model provides not only economic but also environmental benefits in SCM due to the saved input materials. Yet, the implementation of the CE in SCM is still in its infancy [81], which justifies the synthesis of the relevant literature and the prediction of future research trends.

\section{Materials and Methods}

A literature review aims to map and evaluate the subject of the published literature, identify potential research gaps, and highlight the limits of knowledge [101]. In addition, the existing literature should be summarized and categorized based on keywords and topics that determine topics and trends for future research [102].

There are currently several data sources in the scientific literature (Google Scholar, PubMed, Scopus, Web of Science) with different approaches in their research fields. One of the most important scientific bibliographic databases, Scopus has been chosen, which belongs to Elsevier [103]. It contains more than 80 million records [104]. It is one of the main archives of literature that uses peer review as a method for the validation of research. Scopus has a simple interface and helps in the process of visualizing the data through software such as VOSviewer [105].

This analysis was conducted in three stages. Figure 2 contains these stages with the search criteria and results.

The first one consisted of a general evaluation of the scientific literature on SCM. In order to carry out the search process, 'supply chain management' keywords were used, based on the basic concept. Then, the authors focused the search only on the title, because using a broader search retrieved documents not directly related. In addition, using the title, abstract and keywords fields in the search resulted in more than 39,000 records, which is not a manageable amount of data.

The basic sample only included the final version of 6095 documents (4972 of them are considered articles, 588 are book chapters, 429 reviews and 106 books) that have been published on this topic through the end of 2020. 


\section{Analysis of documents published on SCM area}

Search criteria:

TITLE (supply AND chain AND management) AND PUBYEAR <2021 AND (LIMIT-TO (PUBSTAGE, "final")) AND (LIMIT-TO (DOCTYPE, "ar") OR LIMIT-TO (DOCTYPE, "ch") OR LIMIT-TO (DOCTYPE, "re") OR LIMIT-TO (DOCTYPE, "bk"))

Date range: All years to 2020, Publication stage: Final, Document type: Article, Book chapter, Book, Review Languages: All, Disciplines: All

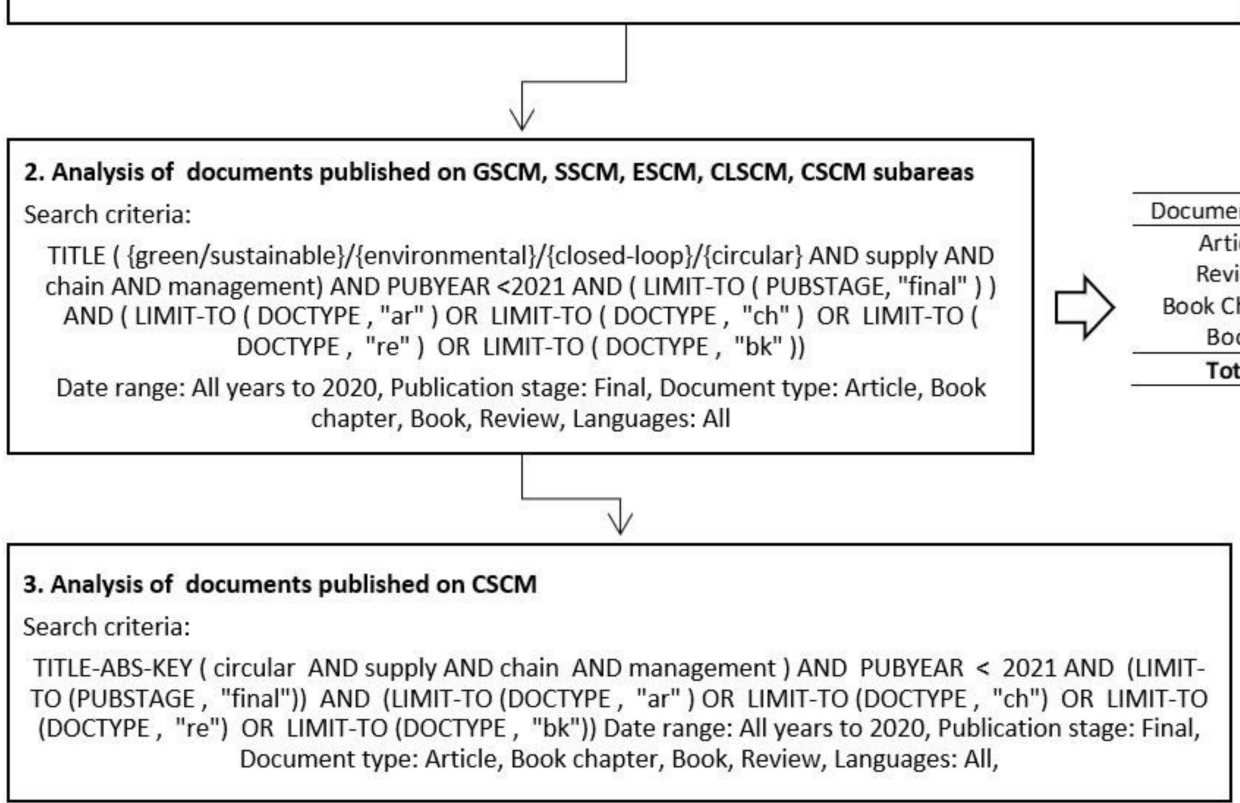

\begin{tabular}{|c|c|}
\hline Document Type & Total \\
\hline Article & 4.972 \\
\hline Review & 429 \\
\hline Book Chapter & 588 \\
\hline Book & 106 \\
\hline Total & 6.095 \\
\hline
\end{tabular}

Figure 2. The main stages of the applied methodology. Search criteria and results.

The metadata of the documents was exported from Scopus to a .csv file, which was analyzed in Excel. It included the author details (names, affiliation, country), document title, abstract, publication date, number of citations and journal name. The tables and some of the figures were made with MS Excel software.

In order to perform descriptive data and bibliometric analyses, the VOSviewer bibliometric tool was used for analyzing co-occurrences. It is a user-friendly tool that allows the direct processing of bibliometric data from the Scopus database and is ideal for visualizing it through networks [106].

In the second stage, Scopus database lists were created according to the subtopics: green supply chain management (GSCM), sustainable supply chain management (SSCM), environmental supply chain management (ESCM), closed-loop supply chain management (CLSCM) and circular supply chain management (CSCM). According to the search criteria, which are detailed in Figure 2, the selected sample included the final version of articles, reviews, books and book chapters. In this stage, only the title search field was used.

Finally, publications in the CSCM subfield were analyzed in a larger sample. In this case, the Scopus search was extended to include the abstract and keywords in addition to the title, assuming that as the number of hits increased, more information would be available about the topic. The search criteria used in this case can also be found in the second figure.

\section{Results and Discussion}

\subsection{Evolution of Scientific Documents on SCM}

In the early 1990s, only a few documents on SCM were written each year. Figure 3 shows that since 2000, the number of publications has come close to one hundred per year. In 2008, a leap can be observed and from 2012 onwards, a significant increase begins. The $\mathrm{R}^{2}=0.9439$ fit curve shows that the number of scientific publications in the field of SCM has increased exponentially. One of the reasons for this is the environmental summit 
held in Rio de Janeiro in 2012 with the participation of 192 UN member states (United Nations Conference on Sustainable Development, Rio+20). The main topic of the event was the development of the green economy and the related institutional system. As the deadline for meeting the Millennium Development Goals set in 2000 approached, new goals became necessary for the period after 2015. Pioneering guidelines on green economic policy were adopted, and issues on the financing of sustainable development were also put into focus. Since 2012, the gap between the accumulated literature and the number of annual publications has increased year by year, indicating that the current research has had outstanding significance in the field of SCM since 2012. Accordingly, in the further analysis, the analyzed period is evaluated in two intervals, from 1990 to 2011 and from 2012 to 2020.

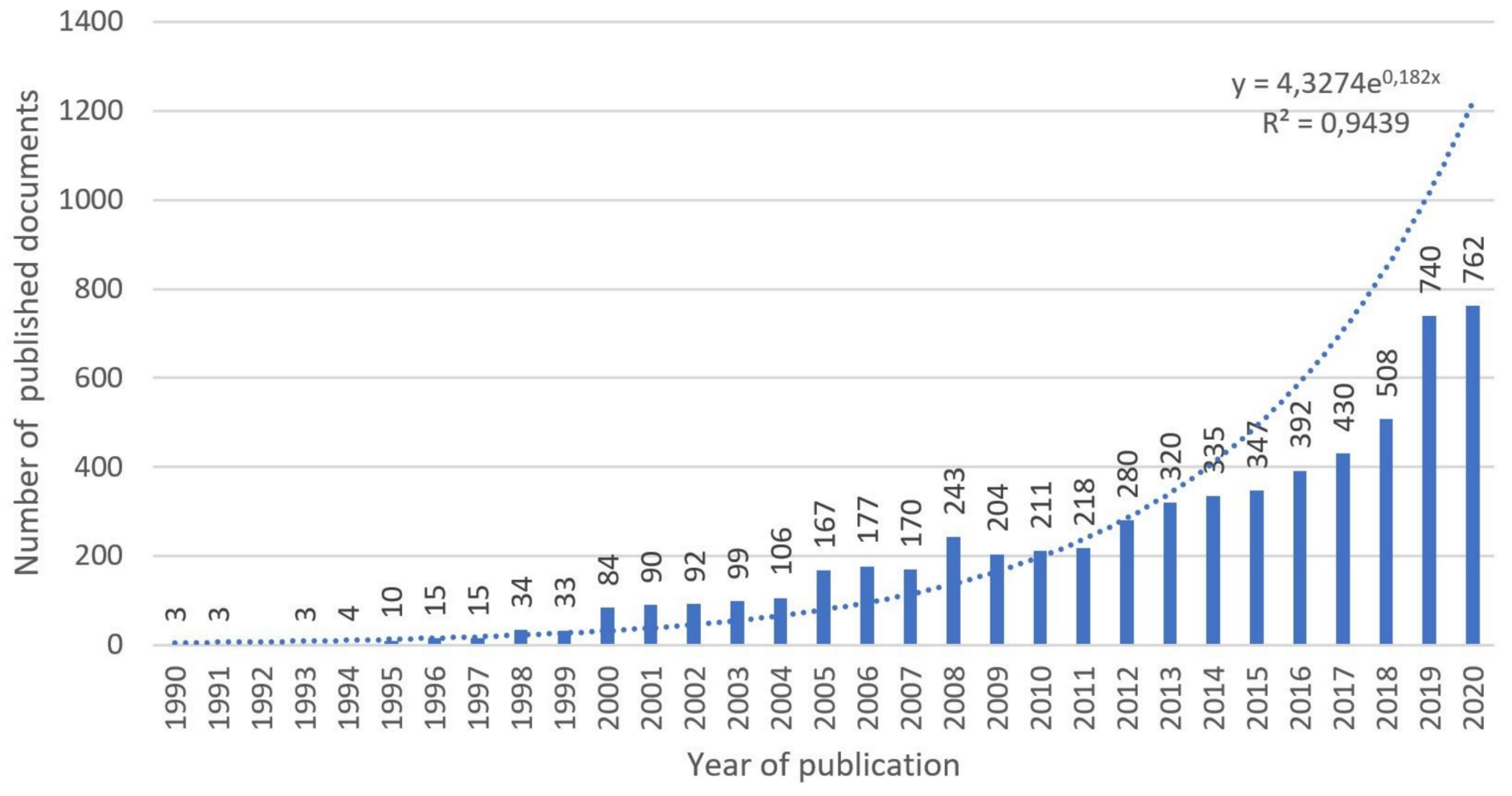

Figure 3. Publication trends of Scopus-based search literature on SCM.

In Table 1, the total link strength indicates the number of links of an item with another item. This value denotes the importance of the keyword in the field since higher value means that it has been linked with others and many times. The occurrences show how many documents the keyword was included in. The table contains only those keywords that are relevant to this study.

Table 1. The number of keyword occurrences in the entire sample.

\begin{tabular}{ccc}
\hline Keyword & Total Link Strength & Occurrences \\
\hline Green supply chain management & 390 & 340 \\
Sustainability & 312 & 241 \\
Sustainable supply chain Management & 147 & 156 \\
Green supply chain & 81 & 76 \\
Environmental management & 65 & 53 \\
GSCM & 94 & 53 \\
Sustainable supply chain & 60 & 44 \\
Environment & 40 & 26 \\
Closed-loop supply chain & 17 & 23 \\
Circular economy & 35 & 20 \\
\hline
\end{tabular}


The co-occurrence network for keywords is shown in Figures 4 and 5. The former contains 85 of the 5984 keywords that appeared in publications between 1990 and 2011 at least 20 times, while the latter shows 87 of the 8230 keywords that appeared between 2012 and 2020. The figures show which areas have become more significant or have developed since 2012.

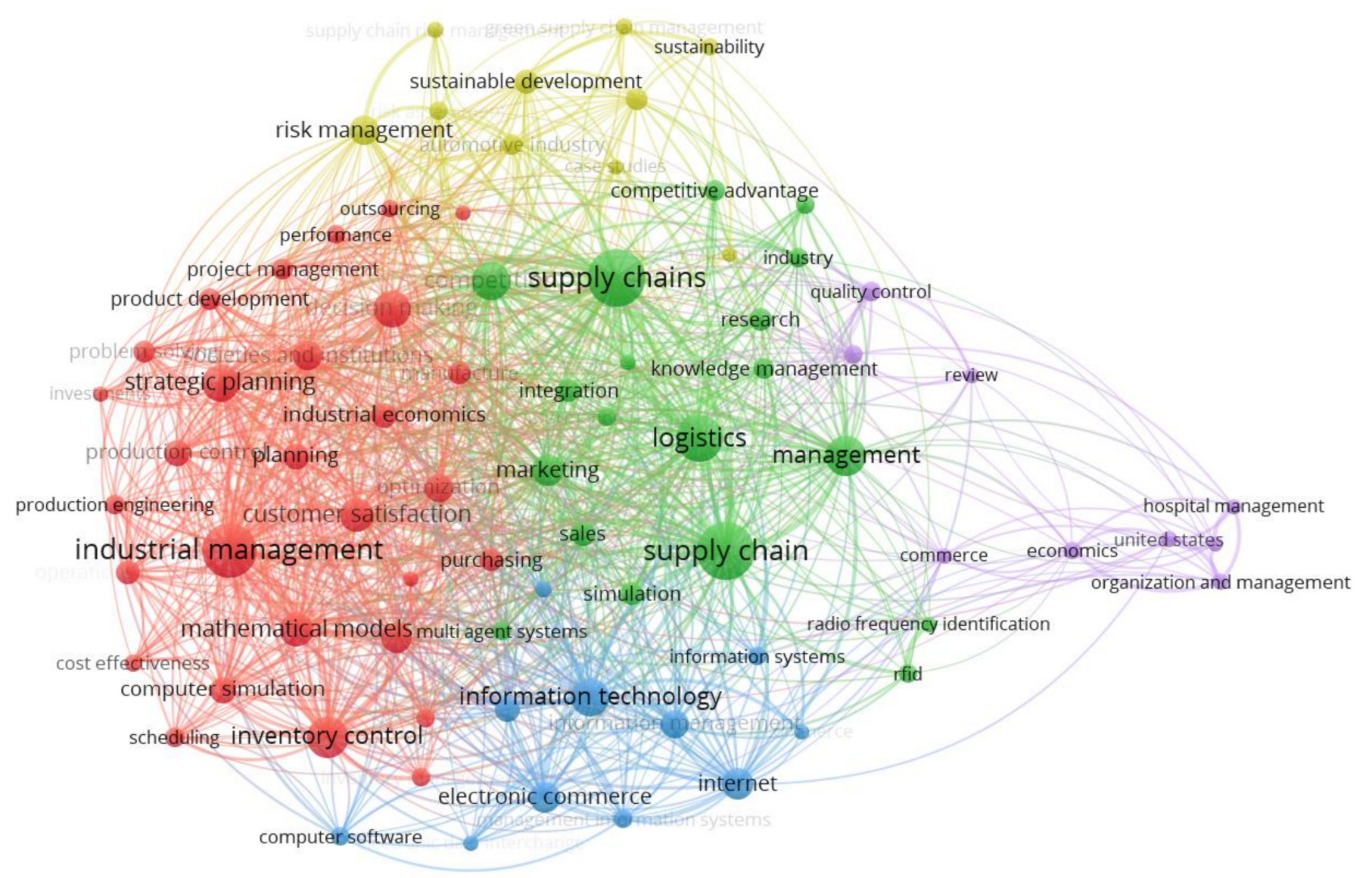

Figure 4. Keyword co-occurrence network regarding SCM between 1990 and 2011.

Figure 5 shows that the topics 'green SCM' (red) and 'sustainable SCM' (yellow) have become significant since 2012, based on keyword occurrences. In addition, the keyword 'environmental management' is already appearing in the network.

Using authors' country of affiliation, it was noticed that the interest in SCM is worldwide, because 186 countries have published at least one document related to the topic, 77 countries have published more than five documents, 47 countries more than 20, and 20 countries more than 100 . This fact suggests that it is a global domain that make researchers from a range of countries interested. In addition, the keyword 'environmental management' is already appearing in the network. Table 2 shows the 10 countries with the highest scientific results in the two periods studied. Together they represent $75 \%$ of all articles in the first period and 58\% in the second period. Prior to 2012, the United States was the country with the most publications. It is followed by the United Kingdom with 232 and then China with 175 documents. The United States has retained its top spot since 2012, followed by India well ahead of China, which is still ranked third. In summary, it can be observed that since 2012 the focus of research has shifted from Europe to the Far East in addition to the USA. 


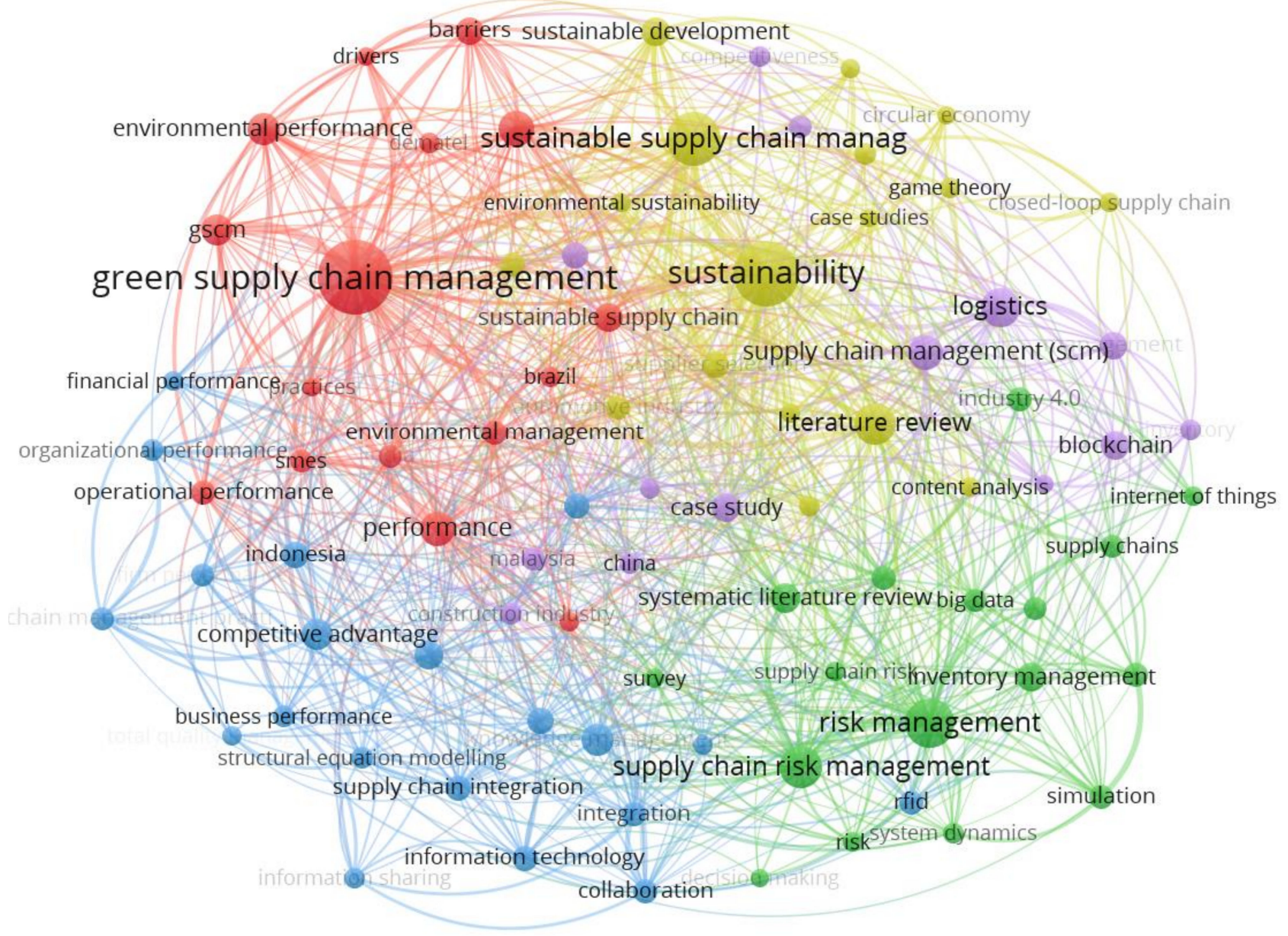

Figure 5. Keyword co-occurrence network regarding SCM between 2012 and 2020.

Table 2. The 10 most publishing countries in the two periods.

\begin{tabular}{cccccc}
\hline \multicolumn{1}{c}{ 1990-2011 } & \multicolumn{3}{c}{ 2012-2020 } \\
\hline Country & Documents & Citations & Country & Documents & Citations \\
\hline United States & 629 & 65,507 & United States & 617 & 20,462 \\
United Kingdom & 232 & 15,351 & India & 491 & 9851 \\
China & 175 & 10,537 & China & 419 & 9046 \\
Germany & 137 & 9024 & United Kingdom & 339 & 13,066 \\
India & 95 & 5442 & Malaysia & 263 & 3181 \\
Australia & 73 & 3046 & Indonesia & 262 & 1203 \\
Hong Kong & 70 & 8845 & Germany & 219 & 7567 \\
Taiwan & 67 & 5297 & Iran & 189 & 2701 \\
Canada & 66 & 6221 & Russia & 155 & 459 \\
Italy & 64 & 3625 & Brazil & 149 & 2160 \\
\hline
\end{tabular}

\subsection{Evolution of Scientific Documents on Subareas of SCM}

Based on the keyword analysis related to SCM publications, the dominant and prominent subareas are revealed. In connection with these 5 subareas, additional queries were performed from the Scopus database (the search criterion is shown in Figure 2).

As it was observed in the publications related to SCM, the jump in 2008 and the significant change starting from 2012 can be well seen in the number of publications related to the subareas (Figure 6). The number of documents published in 2012 on these four topics is 86 . Between 2012 and $2020,89 \%$ of the documents examined were published, which is a clear indicator of the importance that the SCM subareas have gained during the last nine 
years. It can be observed that publications related to circular SCM started to be published in 2017 based on the sample. The strong environmental efforts and measures of the European Union, which is playing a leading role in this area, played a major part in the growth in 2017. The document 'Closing the loop - An EU action plan for the circular economy' published by the European Commission in 2015 deals in detail with the concept of the circular economy and the related definitions [45]. According to the 2017 report 'On the implementation of the Circular Economy Action Plan' [107], the 2015 Commission Communication gave a major impetus to the transition to a circular economy. The legislative proposals put forward focused on long-term goals for waste management and the reduction of waste disposal as well as increasing recycling and reuse. Thanks to this process, the idea of a circular economy has become increasingly embedded in scientific thinking and corporate strategies on the subject.

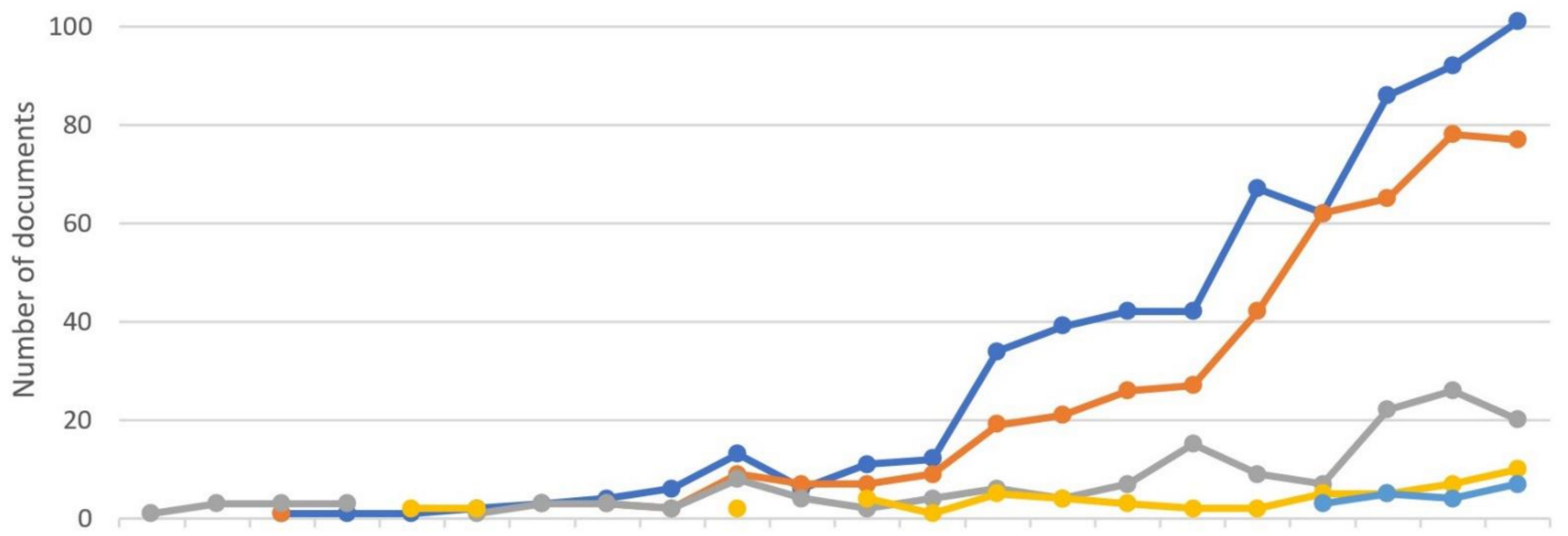

Figure 6. Publication trends on subareas of SCM.

The most significant documents published in the 5 subareas are summarized in Table 3 . The table contains metadata for the three most cited publications by area. Publications with higher citation numbers are review articles for sustainable SCM and green SCM. The article 'From a literature review to a conceptual framework for sustainable supply chain management' [69] published in 2008 is referenced most times (2860 citations). Based on the sample, the second most cited publication is 'Green supply chain management: A state-of-the-art literature review' [93] (2114 citations).

Table 4 shows the journals in which most of the published articles can be found in the sample. The ten journals in the table account for nearly 24 percent of the scientific papers analyzed. The table also shows the number of publications related to the 5 subareas in each journal, which reveals which subfield each major journal is relevant in. 
Table 3. Documents with higher number of citations by SCM subareas.

\begin{tabular}{|c|c|c|c|c|c|c|}
\hline $\mathrm{S}$ & $\mathbf{A}$ & $\mathbf{T}$ & $\mathbf{Y}$ & $\mathbf{S}$ & TC & $\mathbf{R}$ \\
\hline \multirow{3}{*}{$\begin{array}{l}\text { Sustainable } \\
\text { SCM }\end{array}$} & $\begin{array}{l}\text { Seuring S., } \\
\text { Müller M. }\end{array}$ & $\begin{array}{l}\text { From a literature review to a } \\
\text { conceptual framework for } \\
\text { sustainable supply chain } \\
\text { management }\end{array}$ & 2008 & $\begin{array}{l}\text { Journal of Cleaner } \\
\text { Production }\end{array}$ & 2860 & [69] \\
\hline & $\begin{array}{l}\text { Carter C.R., } \\
\text { Rogers D.S. }\end{array}$ & $\begin{array}{l}\text { A framework of sustainable supply } \\
\text { chain management: Moving toward } \\
\text { new theory }\end{array}$ & 2008 & $\begin{array}{l}\text { International Journal of } \\
\text { Physical Distribution } \\
\text { and Logistics Man. }\end{array}$ & 1733 & [108] \\
\hline & Pagell M., Wu Z. & $\begin{array}{l}\text { Building a more complete theory of } \\
\text { sustainable supply chain } \\
\text { management using case studies of } \\
10 \text { exemplars }\end{array}$ & 2009 & $\begin{array}{l}\text { Journal of Supply } \\
\text { Chain Management }\end{array}$ & 857 & [109] \\
\hline \multirow{3}{*}{ Green SCM } & Srivastava S.K. & $\begin{array}{l}\text { Green supply-chain management: A } \\
\text { state-of-the-art literature review }\end{array}$ & 2007 & $\begin{array}{l}\text { International Journal of } \\
\text { Management Reviews }\end{array}$ & 2114 & [93] \\
\hline & Zhu Q., Sarkis J. & $\begin{array}{l}\text { Relationships between operational } \\
\text { practices and performance among } \\
\text { early adopters of green supply chain } \\
\text { management practices in Chinese } \\
\text { manufacturing enterprises }\end{array}$ & 2004 & $\begin{array}{l}\text { Journal of Operations } \\
\text { Management }\end{array}$ & 1491 & [110] \\
\hline & $\begin{array}{l}\text { Sarkis J., Zhu Q., } \\
\text { Lai K.-H. }\end{array}$ & $\begin{array}{l}\text { An organizational theoretic review } \\
\text { of green supply chain } \\
\text { management literature }\end{array}$ & 2011 & $\begin{array}{l}\text { International Journal of } \\
\text { Production Economics }\end{array}$ & 1053 & [111] \\
\hline \multirow{3}{*}{$\begin{array}{l}\text { Environmental } \\
\text { SCM }\end{array}$} & $\begin{array}{l}\text { Vachon S., } \\
\text { Klassen R.D. }\end{array}$ & $\begin{array}{l}\text { Environmental management and } \\
\text { manufacturing performance: The } \\
\text { role of collaboration in the } \\
\text { supply chain }\end{array}$ & 2008 & $\begin{array}{l}\text { International Journal of } \\
\text { Production Economics }\end{array}$ & 962 & [70] \\
\hline & $\begin{array}{l}\text { Walker H., } \\
\text { Di Sisto L., } \\
\text { McBain D. }\end{array}$ & $\begin{array}{l}\text { Drivers and barriers to } \\
\text { environmental supply chain } \\
\text { management practices: Lessons } \\
\text { from the public and private sectors }\end{array}$ & 2008 & $\begin{array}{l}\text { Journal of Purchasing } \\
\text { and Supply } \\
\text { Management }\end{array}$ & 753 & [112] \\
\hline & $\begin{array}{l}\text { Darnall N., Jolley } \\
\text { G.J., Handfield R. }\end{array}$ & $\begin{array}{l}\text { Environmental management } \\
\text { systems and green supply chain } \\
\text { management: Complements } \\
\text { for sustainability? }\end{array}$ & 2008 & $\begin{array}{l}\text { Business Strategy and } \\
\text { the Environment }\end{array}$ & 467 & [113] \\
\hline \multirow{3}{*}{$\begin{array}{l}\text { Closed-loop } \\
\text { SCM }\end{array}$} & $\begin{array}{l}\text { Fleischmann M., } \\
\text { Van Nunen J.A.E.E., } \\
\text { Gräve B. }\end{array}$ & $\begin{array}{l}\text { Integrating Closed-Loop Supply } \\
\text { Chains and Spare-Parts } \\
\text { Management at IBM }\end{array}$ & 2003 & Interfaces & 153 & [114] \\
\hline & $\begin{array}{l}\text { Tseng M., Lim M., } \\
\text { Wong W.P. }\end{array}$ & $\begin{array}{l}\text { Sustainable supply chain } \\
\text { management: A closed-loop } \\
\text { network hierarchical approach }\end{array}$ & 2015 & $\begin{array}{l}\text { Industrial } \\
\text { Management and Data } \\
\text { Systems }\end{array}$ & 121 & [115] \\
\hline & $\begin{array}{l}\text { Spengler T., } \\
\text { Schröter M. }\end{array}$ & $\begin{array}{l}\text { Strategic Management of Spare } \\
\text { Parts in Closed-Loop Supply Chains } \\
\text { - A System Dynamics Approach }\end{array}$ & 2003 & Interfaces & 99 & [116] \\
\hline \multirow{3}{*}{ Circular SCM } & $\begin{array}{l}\text { Genovese A., } \\
\text { Acquaye A.A., } \\
\text { Figueroa A., } \\
\text { Koh S.C.L. }\end{array}$ & $\begin{array}{l}\text { Sustainable supply chain } \\
\text { management and the transition } \\
\text { towards a circular economy: } \\
\text { Evidence and some applications }\end{array}$ & 2017 & $\begin{array}{l}\text { Omega (United } \\
\text { Kingdom) }\end{array}$ & 349 & [99] \\
\hline & $\begin{array}{l}\text { Zeng H., Chen X., } \\
\text { Xiao X., Zhou Z. }\end{array}$ & $\begin{array}{l}\text { Institutional pressures, sustainable } \\
\text { supply chain management, and } \\
\text { circular economy capability: } \\
\text { Empirical evidence from Chinese } \\
\text { eco-industrial park firms }\end{array}$ & 2017 & $\begin{array}{l}\text { Journal of Cleaner } \\
\text { Production }\end{array}$ & 107 & [117] \\
\hline & $\begin{array}{l}\text { Mangla S.K., } \\
\text { Luthra S., } \\
\text { Mishra N., } \\
\text { Singh A., } \\
\text { Rana N.P., } \\
\text { Dora M., } \\
\text { Dwivedi Y. }\end{array}$ & $\begin{array}{l}\text { Barriers to effective circular supply } \\
\text { chain management in a developing } \\
\text { country context }\end{array}$ & 2018 & $\begin{array}{l}\text { Production Planning } \\
\text { and Control }\end{array}$ & 86 & [118] \\
\hline
\end{tabular}


Table 4. Journals with the largest number of publications.

\begin{tabular}{|c|c|c|c|c|c|c|c|c|c|}
\hline Journal & SCM & GSCM & SSCM & ESCM & CLSCM & CSCM & Country & H Index & SJR \\
\hline $\begin{array}{l}\text { Int. Journal of Supply Chain } \\
\text { Management }\end{array}$ & 570 & 52 & 25 & 17 & 0 & 2 & $\begin{array}{l}\text { United } \\
\text { Kingdom }\end{array}$ & 17 & $0.19(\mathrm{Q} 3)$ \\
\hline Supply Chain Management & 138 & 10 & 12 & 3 & 0 & 0 & $\begin{array}{l}\text { United } \\
\text { Kingdom }\end{array}$ & 115 & $2.036(\mathrm{Q} 1)$ \\
\hline $\begin{array}{c}\text { Journal of Cleaner } \\
\text { Production }\end{array}$ & 135 & 52 & 46 & 15 & 7 & 6 & $\begin{array}{l}\text { United } \\
\text { Kingdom }\end{array}$ & 200 & $1.937(\mathrm{Q} 1)$ \\
\hline $\begin{array}{l}\text { Int. Journal of Production } \\
\text { Economics }\end{array}$ & 125 & 10 & 15 & 6 & 1 & 0 & Netherlands & 185 & $2.406(\mathrm{Q} 1)$ \\
\hline $\begin{array}{l}\text { Int. Journal of Production } \\
\text { Research }\end{array}$ & 105 & 7 & 4 & 4 & 1 & 0 & $\begin{array}{l}\text { United } \\
\text { Kingdom }\end{array}$ & 142 & 1.909 (Q1) \\
\hline $\begin{array}{l}\text { Int. Journal of Logistics } \\
\text { Systems and Man. }\end{array}$ & 88 & 13 & 2 & 0 & 0 & 0 & $\begin{array}{l}\text { United } \\
\text { Kingdom }\end{array}$ & 31 & $0.372(\mathrm{Q} 2)$ \\
\hline Sustainability (Switzerland) & 86 & 20 & 36 & 9 & 6 & 1 & Switzerland & 85 & $0.612(\mathrm{Q} 2)$ \\
\hline $\begin{array}{l}\text { Int. Journal of Physical Distr. } \\
\text { and Log. Man. }\end{array}$ & 76 & 2 & 7 & 0 & 0 & 1 & $\begin{array}{l}\text { United } \\
\text { Kingdom }\end{array}$ & 111 & $1.742(\mathrm{Q} 1)$ \\
\hline $\begin{array}{c}\text { Journal of Supply Chain } \\
\text { Management }\end{array}$ & 75 & 2 & 14 & 1 & 0 & 0 & United States & 92 & 3.75 (Q1) \\
\hline $\begin{array}{c}\text { Production Planning and } \\
\text { Control }\end{array}$ & 58 & 10 & 0 & 1 & 0 & 2 & $\begin{array}{l}\text { United } \\
\text { Kingdom }\end{array}$ & 77 & 1.193 (Q1) \\
\hline Total & 1456 & 178 & 161 & 56 & 15 & 12 & & & \\
\hline
\end{tabular}

According to the 2020 SCImago Journal Rank (SJR), 70 percent of these journals fall into the first quartile $(\mathrm{Q} 1), 30$ percent into the second quarter $(\mathrm{Q} 2)$ and 10 percent into the third quarter $(\mathrm{Q})$.

The International Journal of Supply Chain Management leads the ranking of the most important journals by published articles, with 570 articles, accounting for 9.3 percent of the total sample. The main topic of the journal is SCM in manufacturing and services. In second place is the journal Supply Chain Management with 138 articles and 2.2 percent of the total example. This journal focuses primarily on the application of SCM, as well. The Journal of Cleaner Production ranks third with 135 publications. The magazine focuses on the environment and sustainability.

\subsection{Analysis of the Circular Supply Chain Management Area}

Of the documents related to circular supply chain management, the sample contained only a total of 19 pieces, so in order to get more information about the publications on the topic, the search criteria (Figure 1) were extended. In addition to the title, the search results in the abstract and author keywords already contained 343 documents. The annual number of these publications is shown in Figure 7. Based on this, it can be stated that the number of publications in the field of CSCM started to increase in 2016. This tendency is supported by the result reported by Farooque et al., (2018) [81], i.e., the discussion of CE (circular economy) elements in publications related to supply chain sustainability started in the 2000s, and from 2016 onwards there was a growing research interest in the topic. 
140

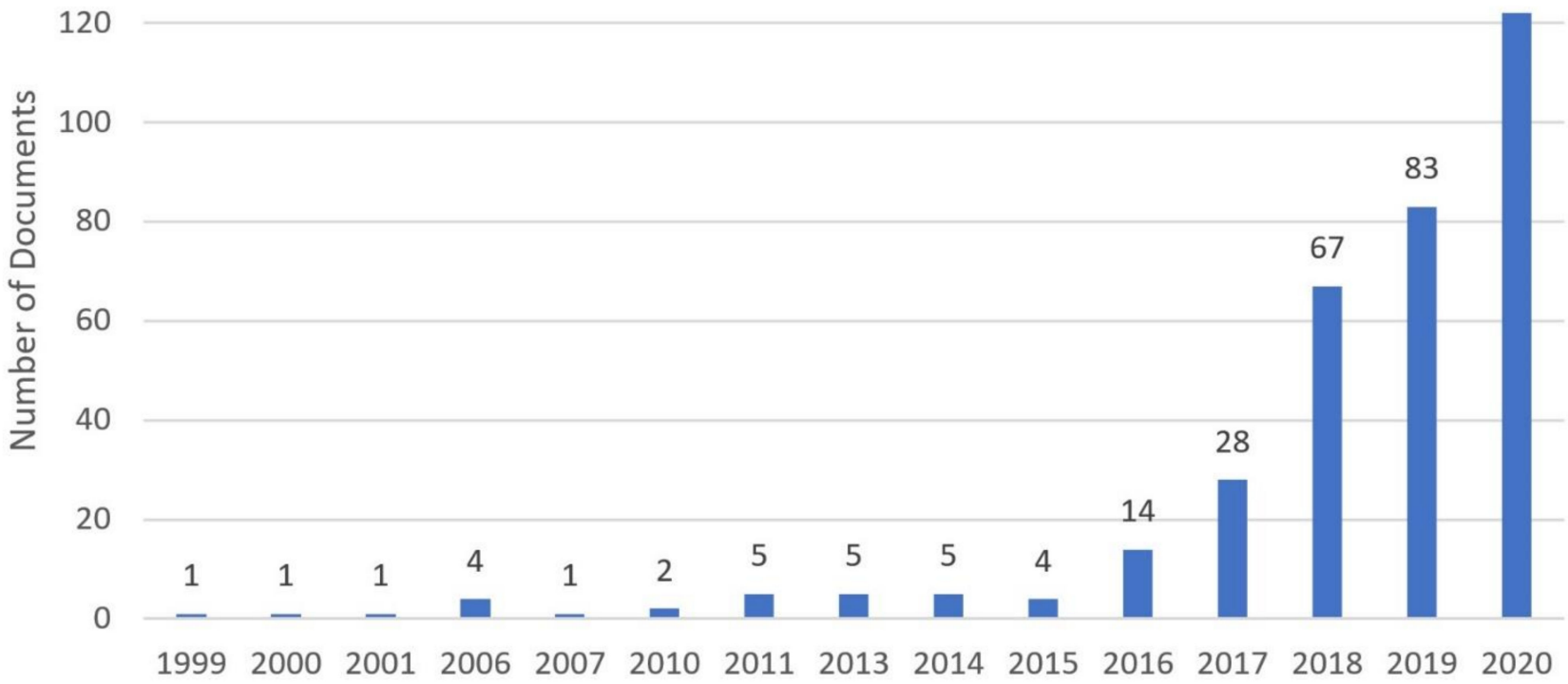

Figure 7. Publication trend of circular SCM.

The keyword coexistence network on CSCM (Figure 8) focuses on 'sustainability', 'waste management', 'recycling', 'environmental management' in addition to 'circular economy', 'supply chain management', 'supply chains', 'life cycle' and 'environmental impact'.

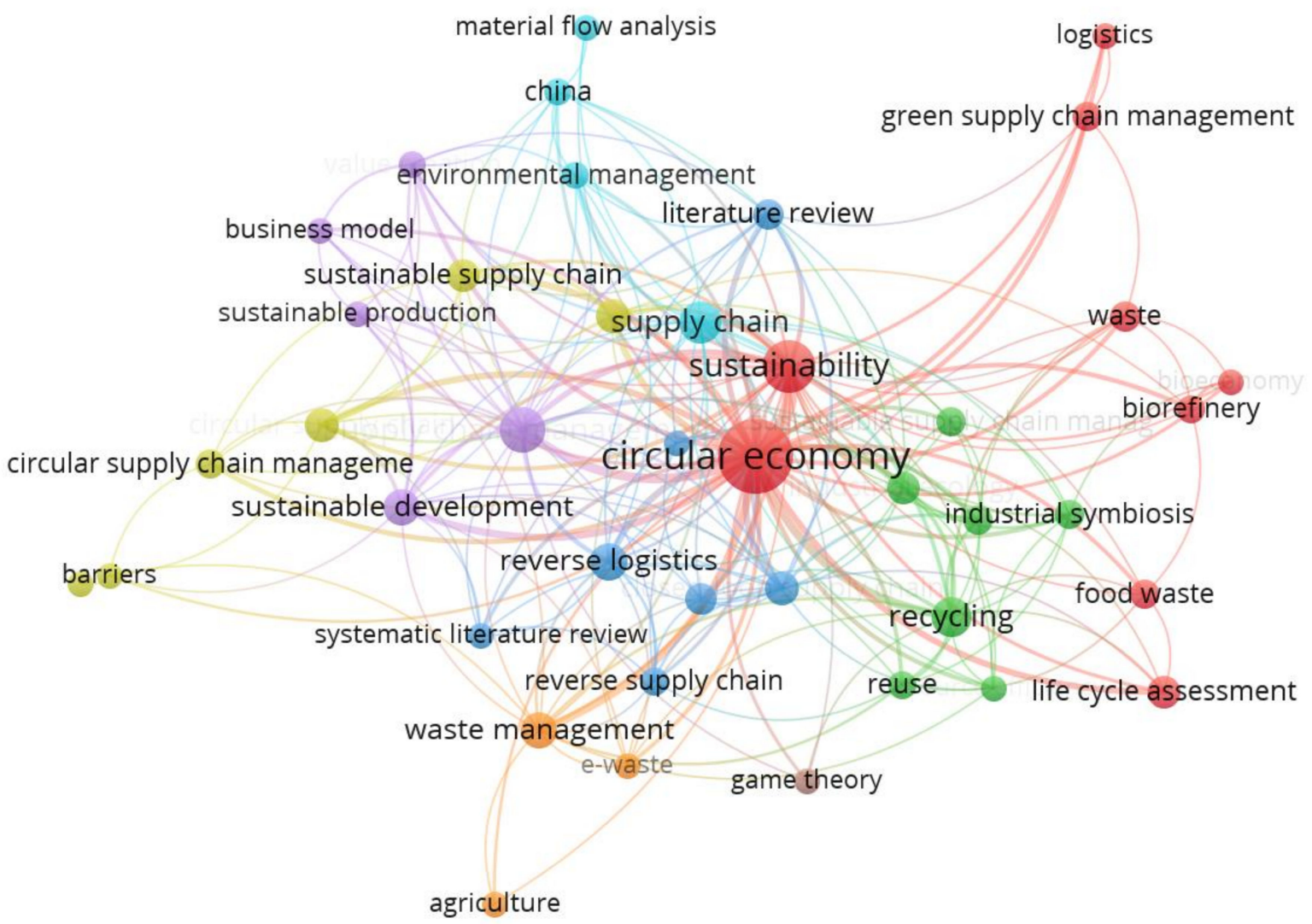

Figure 8. Co-occurrence of the most significant author keywords in the CSCM area. 
From 2020 to date, 11 articles on the impact of COVID-19 have been published worldwide in the field of CSCM. Most articles were published in Sustainability (MDPI) (4 pieces). Based on the citations (42 pieces), the most significant of these articles is the scientific article 'A critical review of the impacts of COVID-19 on the global economy and ecosystems and opportunities for circular economy strategies' written by Ibn-Mohammed et al., (2021) [119]. The article provides an overview of the negative and positive effects of the pandemic and outlines perspectives on how to use it toward a better, low-carbon economy. The article describes the risk of relying on epidemic-driven benefits to achieve sustainable development goals and emphasizes the need for a radical, fundamental structural change in lifestyle dynamics. It approves of rethinking the current model of global economic growth shaped by a linear economic system and maintained by profit-making and energy-intensive production processes and supports a more sustainable model implemented through the framework of a circular economy.

\section{Conclusions}

There is a substantial difference between sustainable and circular economy in emphasizing the importance of each (environmental, social, economic) component. In some cases, a circular economy is not necessarily sustainable, although it can be an important tool in solving sustainability tasks from a corporate perspective.

In previous studies of bibliographic analysis, sample databases were typically created by searching the titles of publications so that the database would contain a manageable number of records. Initially, the abovementioned step was performed, as well. However, after narrowing the topic, the search was extended to include abstract and author keywords in order to get the most accurate results possible.

In this analysis, the basic sample was divided into two periods because the number of publications on the topic increased significantly from 2012 onwards. Thus, we examined how author keywords changed between the two periods. According to the authors' opinion, the outbreak of COVID-19 will also have a major influence on publications on this topic, as over time, more and more scientific articles will be published worldwide analyzing the impact of COVID-19 on SCM and its subfields. Prior to 2012, the keywords 'industrial management' and 'supply chains' were the dominant ones in scientific publications related to SCM, after which 'sustainability' and 'GSCM research directions' came to the fore. This is primarily due to the regulations on this issue and partly to the well-cited basic studies published on these topics in 2007-2008. Circularity began appearing in SCM a decade later, due to relevant EU policies.

There was also a spatial change in the research. Although the US still plays a key role in the field, the previous European research bases have been replaced by Far Eastern dominance. Based on this study, it can be clearly established that temporal and spatial changes are interrelated. COVID-19 may have an impact on the further spread of CSCM, primarily through lifestyle changes and a focus on sustainability (MDPI, Sustainability, 4 articles).

International commitments clearly emphasize the need to take greater account of sustainability in the next decade. All of these will make a significant contribution to achieving the sustainable development goals set out in 2015 and to implementing the guidelines and policies defined since then. This idea also prevails in the development of supply chains, which makes the spread of the circular economic model probable in the future.

Author Contributions: Conceptualization, P.L., A.B., Z.G., E.P. and K.N.; methodology, P.L., O.M.A.M. and P.B.; software, P.L. and O.M.A.M.; formal analysis, P.L. and O.M.A.M.; investigation, P.L., A.B., Z.G., E.P. and K.N.; resources, P.L., A.B., Z.G., E.P., N.T.-K. and K.N.; data curation, P.L., O.M.A.M., P.B. and K.N.; writing—original draft preparation, P.L., A.B., Z.G., E.P. and K.N.; writing—review and editing, P.L., A.B., Z.G., E.P. and K.N.; visualization, P.L., O.M.A.M. and Z.G.; supervision, P.L., A.B., P.B., E.P. and K.N.; project administration, Z.G., E.P., N.T.-K. and K.N.; funding acquisition, A.B., Z.G., E.P., N.T.-K. and K.N. All authors have read and agreed to the published version of the manuscript. 
Funding: This publication/research has been supported by the National Research, Development and Innovation Office through the project nr. 2019-1.3.1-KK-2019-00015, titled 'Establishment of a circular economy-based sustainability competence center at the University of Pannonia'.

Institutional Review Board Statement: Not applicable.

Informed Consent Statement: Not applicable.

Data Availability Statement: Not applicable.

Conflicts of Interest: The authors declare no conflict of interest.

\section{References}

1. Belaud, J.-P.; Adoue, C.; Vialle, C.; Chorro, A.; Sablayrolles, C. A circular economy and industrial ecology toolbox for developing an eco-industrial park: Perspectives from French policy. Clean Technol. Environ. Policy 2019, 21, 967-985. [CrossRef]

2. Plank, B.; Eisenmenger, N.; Schaffartzik, A.; Wiedenhofer, D. International trade drives global resource use: A structural decomposition analysis of raw material consumption from 1990-2010. Environ. Sci. Technol. 2018, 52, 4190-4198. [CrossRef]

3. Saberi, S.; Kouhizadeh, M.; Sarkis, J.; Shen, L. Blockchain technology and its relationships to sustainable supply chain management. Int. J. Prod. Res. 2019, 57, 2117-2135. [CrossRef]

4. Villena, V.H.; Gioia, D.A. A More Sustainable Supply Chain. Harvard Business Review, March 2020, pp. 84-92.

5. Chu, C.-Y.; Park, K.; Kremer, G.E. A global supply chain risk management framework: An application of text-mining to identify region-specific supply chain risks. Adv. Eng. Inform. 2020, 45, 101053. [CrossRef]

6. Srivastava, M.; Rogers, H. Managing global supply chain risks: Effects of the industry sector. Int. J. Logist. Res. Appl. 2021, 1-24. [CrossRef]

7. Bowon, K. Supply Chain Management: A Learning Perspective; Cambridge University Press: Cambridge, UK, 2018.

8. Zimmer, K.; Fröhling, M.; Breun, P.; Schultmann, F. Assessing social risks of global supply chains: A quantitative analytical approach and its application to supplier selection in the German automotive industry. J. Clean. Prod. 2017, 149, 96-109. [CrossRef]

9. Koberg, E.; Longoni, A. A systematic review of sustainable supply chain management in global supply chains. J. Clean. Prod. 2019, 207, 1084-1098. [CrossRef]

10. Olivier, M.M.; Wilson, B.P.; Howard, J.L. Measuring localisation regionally to form a Bhutanese index. Sustainability 2016, 8, 690. [CrossRef]

11. Olivier, M.M.; Wilson, B.P.; Howard, J.L. Determining localisation metrics. Soc. Indic. Res. 2017, 131, 467-487. [CrossRef]

12. Benedek, Z.; Fertő, I.; Szente, V. The multiplier effects of food relocalization: A systematic review. Sustainability 2020, $12,3524$. [CrossRef]

13. Németh, K.; Birkner, Z.; Katona, A.; Göllény-Kovács, N.; Bai, A.; Balogh, P.; Gabnai, Z.; Péter, E. Can Energy be a “Local Product” Again? Hungarian Case Study. Sustainability 2020, 12, 1118. [CrossRef]

14. UN. Transforming Our World: The 2030 Agenda for Sustainable Development; United Nations: New York, NY, USA, 2015.

15. Hyland, J.; Crehan, P.; Colantuono, F.; Macken-Walsh, Á. The Significance of Short Food Supply Chains: Trends and Bottlenecks from the SKIN Thematic Network. Stud. Agric. Econ. 2019, 121, 59-66. [CrossRef]

16. EEA. Circular Economy in Europe-Developing the Knowledge Base; Publications Office of the European Union: Luxembourg, 2016.

17. Lakner, Z.; Plasek, B.; Kiss, A.; Soós, S.; Temesi, Á. Derailment or Turning Point? The Effect of the COVID-19 Pandemic on Sustainability-Related Thinking. Sustainability 2021, 13, 5506. [CrossRef]

18. Nikulski, J.S.; Ritthoff, M.; Gries, N.V. The potential and limitations of critical raw material recycling: The case of LED lamps. Resources 2021, 10, 37. [CrossRef]

19. Bringezu, S. Toward science-based and knowledge-based targets for global sustainable resource use. Resources $2019,8,140$. [CrossRef]

20. Bringezu, S.; Potočnik, J.; Schandl, H.; Lu, Y.; Ramaswami, A.; Swilling, M.; Suh, S. Multi-scale governance of sustainable natural resource use - challenges and opportunities for monitoring and institutional development at the national and global level. Sustainability 2016, 8, 778. [CrossRef]

21. Oberle, B.; Bringezu, S.; Hatfield-Dodds, S.; Hellweg, S.; Schandl, H.; Clement, J.; Cabernard, L.; Che, N.; Chen, D.; Droz-Georget, H.; et al. Global Resources Outlook 2019: Natural Resources for the Future We Want; United Nations: Nairobi, Kenya, $2019 ;$ p. 162.

22. Zepf, V.; Reller, A.; Rennie, C.; Ashfield, M.; Simmons, J.B.P. Materials Critical to the Energy Industry. An Introduction, 2nd ed.; BP p.l.c.: London, UK, 2014.

23. Comission, E. The European Green Deal; European Comission: Brussels, Belgium, 2019.

24. Kunzig, R. Is a world without trash possible? National Geographic, 18 February 2020, pp. 46-69.

25. Vita, G.; Hertwich, E.G.; Stadler, K.; Wood, R. Connecting global emissions to fundamental human needs and their satisfaction. Environ. Res. Lett. 2019, 14, 014002. [CrossRef]

26. Hertwich, E.; van der Voet, E.; Suh, S.; Tukker, A.H.M.; Kazmierczyk, P.; Lenzen, M.; Mc-Neely, J.; Moriguchi, Y.; UNEP. Assessing the Environmental Impacts of Consumption and Production: Priority Products and Materials. A Report of the Working Group on Environmental Impacts of Products and Materials to the International Panel for Sustainable Resource Management; United Nations Environment Programme: Nairobi, Kenya, 2010. 
27. IRP. Assessing Global Resource Use. A Systems Approach to Resource Efficiency and Pollution Reduction; United Nations Environment Programme: Nairobi, Kenya, 2017; p. 104.

28. Georgantzis Garcia, D.; Kipnis, E.; Vasileiou, E.; Solomon, A. Consumption in the Circular Economy: Learning from Our Mistakes. Sustainability 2021, 13, 601. [CrossRef]

29. Adami, L.; Schiavon, M. From Circular Economy to Circular Ecology: A Review on the Solution of Environmental Problems through Circular Waste Management Approaches. Sustainability 2021, 13, 925. [CrossRef]

30. Ness, D.A.; Xing, K. Toward a Resource-Efficient Built Environment: A Literature Review and Conceptual Model. J. Ind. Ecol. 2017, 21, 572-592. [CrossRef]

31. Singh, J.; Ordoñez, I. Resource recovery from post-consumer waste: Important lessons for the upcoming circular economy. J. Clean. Prod. 2016, 134, 342-353. [CrossRef]

32. Song, Q.; Li, J.; Zeng, X. Minimizing the increasing solid waste through zero waste strategy. J. Clean. Prod. 2015, 104, 199-210. [CrossRef]

33. Allwood, J.M.; Ashby, M.F.; Gutowski, T.G.; Worrell, E. Material efficiency: A white paper. Resour. Conserv. Recycl. 2011, 55, 362-381. [CrossRef]

34. Hislop, H.; Hill, J. Reinventing the Wheel: A Circular Economy for Resource Security. Green Alliance, 5 October 2011, p. 52.

35. Preston, F. A Global Redesign? Shaping the Circular Economy. Chatham House Briefing, 1 March 2012, p. 20.

36. EMF. Towards the Circular Economy: Opportunities for the Consumer Goods Sector; Ellen MacArthur Foundation: Cowes, UK, 2013; p. 112.

37. Geissdoerfer, M.; Morioka, S.N.; de Carvalho, M.M.; Evans, S. Business models and supply chains for the circular economy. J. Clean. Prod. 2018, 190, 712-721. [CrossRef]

38. Antikainen, M.; Valkokari, K. A framework for sustainable circular business model innovation. Technol. Innov. Manag. Rev. 2016, 6, 5-12. [CrossRef]

39. Bastein, T.; Roelofs, E.; Rietveld, E.; Hoogendoorn, A. Opportunities for a Circular Economy in the Netherlands; TNO: Delft, The Netherlands, 2013.

40. Cecchin, A.; Salomone, R.; Deutz, P.; Raggi, A.; Cutaia, L. Relating Industrial Symbiosis and Circular Economy to the Sustainable Development Debate. In Industrial Symbiosis for the Circular Economy. Strategies for Sustainability; Salomone, R., Cecchin, A., Deutz, P., Raggi, A., Cutaia, L., Eds.; Springer: Berlin/Heidelberg, Germany, 2020; pp. 1-25. [CrossRef]

41. Teräs, J.; Mikkola, N. What is industrial symbiosis? Nordregio News, 7 April 2016.

42. Allenby, B. The ontologies of industrial ecology? Prog. Ind. Ecol. Int. J. 2006, 3, 28-40. [CrossRef]

43. Frosch, R.A.; Gallopoulos, N.E. Strategies for manufacturing. Sci. Am. 1989, 261, 144-153. [CrossRef]

44. Maranesi, C.; De Giovanni, P. Modern circular economy: Corporate strategy, supply chain, and industrial symbiosis. Sustainability 2020, 12, 9383. [CrossRef]

45. EC. Closing the Loop-An EU Action Plan for the Circular Economy; European Commission: Brussels, Belgium, 2015.

46. Reh, L. Process engineering in circular economy. Particuology 2013, 11, 119-133. [CrossRef]

47. Yi, S.; Wu, N.; Luo, P.; Wang, Q.; Shi, F.; Zhang, Q.; Ma, J. Agricultural heritage in disintegration: Trends of agropastoral transhumance on the southeast Tibetan Plateau. Int. J. Sustain. Dev. World Ecol. 2008, 15, 273-283. [CrossRef]

48. Alhawari, O.; Awan, U.; Bhutta, M.K.S.; Ülkü, M.A. Insights from circular economy literature: A review of extant definitions and unravelling paths to future research. Sustainability 2021, 13, 859. [CrossRef]

49. Kirchherr, J.; Reike, D.; Hekkert, M. Conceptualizing the circular economy: An analysis of 114 definitions. Resour. Conserv. Recycl. 2017, 127, 221-232. [CrossRef]

50. Velte, J.C.; Steinhilper, R. Complexity in a Circular Economy: A Need for Rethinking Complexity Management Strategies. In Proceedings of the World Congress on Engineering, London, UK, 29 June-1 July 2016; pp. 1-6.

51. Birat, J.P. Life-cycle assessment, resource efficiency and recycling. Metall. Res. Technol. 2015, 112, 1-24. [CrossRef]

52. EC. EU Energy Statistical Pocketbook and Country Datasheets. Country Datasheets; European Commission: Brussels, Belgium, 2020.

53. Towers, N.; Abushaikha, I.; Ritchie, J.; Holter, A. The impact of phenomenological methodology development in supply chain management research. Supply Chain Manag. Int. J. 2020, 25, 443-456. [CrossRef]

54. Ellram, L.M.; Cooper, M.C. Supply chain management: It's all about the journey, not the destination. J. Supply Chain Manag. 2014, 50, 8-20. [CrossRef]

55. Lambert, D.M.; Cooper, M.C.; Pagh, J.D. Supply chain management: Implementation issues and research opportunities. Int. J. Logist. Manag. 1998, 9, 1-20. [CrossRef]

56. Mentzer, J.T.; DeWitt, W.; Keebler, J.S.; Min, S.; Nix, N.W.; Smith, C.D.; Zacharia, Z.G. Defining supply chain management. J. Bus. Logist. 2001, 22, 1-25. [CrossRef]

57. Rajeev, A.; Pati, R.K.; Padhi, S.S.; Govindan, K. Evolution of sustainability in supply chain management: A literature review. J. Clean. Prod. 2017, 162, 299-314. [CrossRef]

58. AlKhidir, T.; Zailani, S. Going green in supply chain towards environmental sustainability. Glob. J. Environ. Res. 2009, 3, $246-251$.

59. Centobelli, P.; Cerchione, R.; Esposito, E. Developing the WH2 framework for environmental sustainability in logistics service providers: A taxonomy of green initiatives. J. Clean. Prod. 2017, 165, 1063-1077. [CrossRef]

60. Centobelli, P.; Cerchione, R.; Esposito, E. Environmental sustainability and energy-efficient supply chain management: A review of research trends and proposed guidelines. Energies 2018, 11, 275. [CrossRef] 
61. Aoki, M. The Co-Operative Game Theory of the Firm; Oxford University Press: New York, NY, USA, 1984.

62. Klein, B.; Crawford, R.G.; Alchian, A.A. Vertical integration, appropriable rents, and the competitive contracting process. J. Law Econ. 1978, 21, 297-326. [CrossRef]

63. Lamming, R. Beyond partnership: Strategies for innovation and lean supply. J. Oper. Res. Soc. 1994, 45, 238-239. [CrossRef]

64. McIvor, R. A practical framework for understanding the outsourcing process. Supply Chain Manag. 2000, 5, 22-36. [CrossRef]

65. Dubey, R.; Gunasekaran, A.; Childe, S.J.; Papadopoulos, T.; Wamba, S.F. World class sustainable supply chain management: Critical review and further research directions. Int. J. Logist. Manag. 2017, 28, 332-362. [CrossRef]

66. Roehrich, J.K.; Hoejmose, S.U.; Overland, V. Driving green supply chain management performance through supplier selection and value internalisation: A self-determination theory perspective. Int. J. Oper. Prod. Manag. 2017, 37, 489-509. [CrossRef]

67. Sari, K. A novel multi-criteria decision framework for evaluating green supply chain management practices. Comput. Ind. Eng. 2017, 105, 338-347. [CrossRef]

68. Laari, S.; Töyli, J.; Ojala, L. Supply chain perspective on competitive strategies and green supply chain management strategies. J. Clean. Prod. 2017, 141, 1303-1315. [CrossRef]

69. Seuring, S.; Müller, M. From a literature review to a conceptual framework for sustainable supply chain management. J. Clean. Prod. 2008, 16, 1699-1710. [CrossRef]

70. Vachon, S.; Klassen, R.D. Environmental management and manufacturing performance: The role of collaboration in the supply chain. Int. J. Prod. Econ. 2008, 111, 299-315. [CrossRef]

71. Grosvold, J.; Hoejmose, S.U.; Roehrich, J.K. Squaring the circle: Management, measurement and performance of sustainability in supply chains. Supply Chain Manag. 2014, 19, 292-305. [CrossRef]

72. Hafezalkotob, A. Competition, cooperation, and coopetition of green supply chains under regulations on energy saving levels. Transp. Res. Part E Logist. Transp. Rev. 2017, 97, 228-250. [CrossRef]

73. Reefke, H.; Sundaram, D. Key themes and research opportunities in sustainable supply chain management-identification and evaluation. Omega 2017, 66, 195-211. [CrossRef]

74. Costantini, V.; Crespi, F.; Marin, G.; Paglialunga, E. Eco-innovation, sustainable supply chains and environmental performance in European industries. J. Clean. Prod. 2017, 155, 141-154. [CrossRef]

75. Hazen, B.T.; Mollenkopf, D.A.; Wang, Y. Remanufacturing for the circular economy: An examination of consumer switching behavior. Bus. Strategy Environ. 2017, 26, 451-464. [CrossRef]

76. Shaharudin, M.S.; Fernando, Y.; Jabbour, C.J.C.; Sroufe, R.; Jasmi, M.F.A. Past, present, and future low carbon supply chain management: A content review using social network analysis. J. Clean. Prod. 2019, 218, 629-643. [CrossRef]

77. Ansari, Z.N.; Kant, R. A state-of-art literature review reflecting 15 years of focus on sustainable supply chain management. $J$. Clean. Prod. 2017, 142, 2524-2543. [CrossRef]

78. Dubey, R.; Gunasekaran, A.; Papadopoulos, T.; Childe, S.J.; Shibin, K.; Wamba, S.F. Sustainable supply chain management: Framework and further research directions. J. Clean. Prod. 2017, 142, 1119-1130. [CrossRef]

79. Cerchione, R.; Esposito, E. A systematic review of supply chain knowledge management research: State of the art and research opportunities. Int. J. Prod. Econ. 2016, 182, 276-292. [CrossRef]

80. Gurtu, A.; Searcy, C.; Jaber, M.Y. An analysis of keywords used in the literature on green supply chain management. Manag. Res. Rev. Emerald Group Publ. 2015, 38, 166-194. [CrossRef]

81. Farooque, M.; Zhang, A.; Thürer, M.; Qu, T.; Huisingh, D. Circular supply chain management: A definition and structured literature review. J. Clean. Prod. 2019, 228, 882-900. [CrossRef]

82. Ahi, P.; Searcy, C. An analysis of metrics used to measure performance in green and sustainable supply chains. J. Clean. Prod. 2015, 86, 360-377. [CrossRef]

83. Geissdoerfer, M.; Savaget, P.; Bocken, N.; Hultink, E.J. The circular economy-A new sustainability paradigm? J. Clean. Prod. 2017, 143, 757-768. [CrossRef]

84. Simons, N. What's the Difference Between Green, Sustainable, Eco-Friendly, Ethical, Fair Trade, Clean, Organic, Non-Toxic, and Conscious? Ecocult. 08.05.2018.

85. Loiseau, E.; Saikku, L.; Antikainen, R.; Droste, N.; Hansjürgens, B.; Pitkänen, K.; Leskinen, P.; Kuikman, P.; Thomsen, M. Green economy and related concepts: An overview. J. Clean. Prod. 2016, 139, 361-371. [CrossRef]

86. UNEP. Towards a Green Economy: Pathways to Sustainable Development and Poverty Eradication. A Synthesis for Policy Makers; United Nations: Nairobi, Kenya, 2011; p. 52.

87. EC. Communication from the Commission of the European Parliament, the Council, the European Economic and Social Committee and the Committee of the Regions: "Innovating for Sustainable Growth: A Bioeconomy for Europe."; European Commission: Brussels, Belgium, 2012.

88. UNEP. Using Product-Service Systems to Enhance Sustainable Public Procurement. Technical Report; United Nations: Nairobi, Kenya, 2015; p. 46.

89. EMF. Towards the Circular Economy: Economic and Business Rationale for an Accelerated Transition; Ellen MacArthur Foundation: Cowes, UK; 2013; p. 98.

90. De Angelis, R.; Howard, M.; Miemczyk, J. Supply chain management and the circular economy: Towards the circular supply chain. Prod. Plan. Control 2018, 29, 425-437. [CrossRef]

91. Simon, S. What's the difference between Circular Economy and Sustainability? Collective Green, 29 December 2020. 
92. Ahi, P.; Searcy, C. A comparative literature analysis of definitions for green and sustainable supply chain management. J. Clean. Prod. 2013, 52, 329-341. [CrossRef]

93. Srivastava, S.K. Green supply-chain management: A state-of-the-art literature review. Int. J. Manag. Rev. 2007, 9, 53-80. [CrossRef]

94. Zsidisin, G.A.; Siferd, S.P. Environmental purchasing: A framework for theory development. Eur. J. Purch. Supply Manag. 2001, 7, 61-73. [CrossRef]

95. Guide, V.D.R., Jr.; Van Wassenhove, L.N. Closed-loop supply chains: An introduction to the feature issue (part 1). Prod. Oper. Manag. 2006, 15, 345-350. [CrossRef]

96. Khorshidvand, B.; Soleimani, H.; Sibdari, S.; Esfahani, M.M.S. A hybrid modeling approach for green and sustainable closed-loop supply chain considering price, advertisement and uncertain demands. Comput. Ind. Eng. 2021, 157, 107326. [CrossRef]

97. Morali, O.; Searcy, C. A review of sustainable supply chain management practices in Canada. J. Bus. Ethics 2013, 117, 635-658. [CrossRef]

98. EMF. Towards the Circular Economy: Accelerating the Scale-Up across Global Supply Chains; Ellen MacArthur Foundation: Cowes, UK; World Economic Forum: Cologny, Switzerland; McKinsey \& Company: New York, NY, USA, 2014; p. 41.

99. Genovese, A.; Acquaye, A.A.; Figueroa, A.; Koh, S.L. Sustainable supply chain management and the transition towards a circular economy: Evidence and some applications. Omega 2017, 66, 344-357. [CrossRef]

100. Nasir, M.H.A.; Genovese, A.; Acquaye, A.A.; Koh, S.; Yamoah, F. Comparing linear and circular supply chains: A case study from the construction industry. Int. J. Prod. Econ. 2017, 183, 443-457. [CrossRef]

101. Tranfield, D.; Denyer, D.; Smart, P. Towards a methodology for developing evidence-informed management knowledge by means of systematic review. Br. J. Manag. 2003, 14, 207-222. [CrossRef]

102. Gong, R.; Xue, J.; Zhao, L.; Zolotova, O.; Ji, X.; Xu, Y. A bibliometric analysis of green supply chain management based on the Web of Science (WOS) platform. Sustainability 2019, 11, 3459. [CrossRef]

103. Elsevier. Scopus_Research Intelligence. 2019. Available online: https://www.elsevier.com/_data/assets/pdf_file/0017/11453 3/Scopus_GlobalResearch_Factsheet2019_FINAL_WEB.pdf (accessed on 12 April 2021).

104. Niñerola, A.; Sánchez-Rebull, M.-V.; Hernández-Lara, A.-B. Tourism research on sustainability: A bibliometric analysis. Sustainability 2019, 11, 1377. [CrossRef]

105. Duque-Acevedo, M.; Belmonte-Ureña, L.J.; Yakovleva, N.; Camacho-Ferre, F. Analysis of the circular economic production models and their approach in agriculture and agricultural waste biomass management. Int. J. Environ. Res. Public Health 2020, 17, 9549. [CrossRef] [PubMed]

106. Van Eck, N.J.; Waltman, L. Software survey: VOSviewer, a computer program for bibliometric mapping. Scientometrics 2010, 84 523-538. [CrossRef] [PubMed]

107. Comission, E. On the Implementation of the Circular Economy Action Plan, Brussels; European Comission: Brussels, Belgium, 2017.

108. Carter, C.R.; Rogers, D.S. A Framework of Sustainable Supply Chain Management: Moving toward New Theory. Int. J. Phys. Distrib. Logist. Manag. 2008, 38, 360-387. [CrossRef]

109. Pagell, M.; Wu, Z. Building a more complete theory of sustainable supply chain management using case studies of 10 exemplars. J. Supply Chain Manag. 2009, 45, 37-56. [CrossRef]

110. Zhu, Q.; Sarkis, J. Relationships between operational practices and performance among early adopters of green supply chain management practices in Chinese manufacturing enterprises. J. Oper. Manag. 2004, 22, 265-289. [CrossRef]

111. Sarkis, J.; Zhu, Q.; Lai, K.-h. An organizational theoretic review of green supply chain management literature. Int. J. Prod. Econ. 2011, 130, 1-15. [CrossRef]

112. Walker, H.; Di Sisto, L.; McBain, D. Drivers and barriers to environmental supply chain management practices: Lessons from the public and private sectors. J. Purch. Supply Manag. 2008, 14, 69-85. [CrossRef]

113. Darnall, N.; Jolley, G.J.; Handfield, R. Environmental management systems and green supply chain management: Complements for sustainability? Bus. Strategy Environ. 2008, 17, 30-45. [CrossRef]

114. Fleischmann, M.; Van Nunen, J.A.; Gräve, B. Integrating closed-loop supply chains and spare-parts management at IBM. Interfaces 2003, 33, 44-56. [CrossRef]

115. Tseng, M.; Lim, M.; Wong, W.P. Sustainable supply chain management: A closed-loop network hierarchical approach. Ind. Manag. Data Syst. 2015, 115, 436-461. [CrossRef]

116. Spengler, T.; Schröter, M. Strategic management of spare parts in closed-loop supply chains-A system dynamics approach. Interfaces 2003, 33, 7-17. [CrossRef]

117. Zeng, H.; Chen, X.; Xiao, X.; Zhou, Z. Institutional pressures, sustainable supply chain management, and circular economy capability: Empirical evidence from Chinese eco-industrial park firms. J. Clean. Prod. 2017, 155, 54-65. [CrossRef]

118. Mangla, S.K.; Luthra, S.; Mishra, N.; Singh, A.; Rana, N.P.; Dora, M.; Dwivedi, Y. Barriers to effective circular supply chain management in a developing country context. Prod. Plan. Control 2018, 29, 551-569. [CrossRef]

119. Ibn-Mohammed, T.; Mustapha, K.; Godsell, J.; Adamu, Z.; Babatunde, K.; Akintade, D.; Acquaye, A.; Fujii, H.; Ndiaye, M.; Yamoah, F. A critical review of the impacts of COVID-19 on the global economy and ecosystems and opportunities for circular economy strategies. Resour. Conserv. Recycl. 2021, 164, 105169. [CrossRef] [PubMed] 